\title{
ИСПРАВКА
}

У претходном броју Социолошког прегледа (бр. 3), техничком грешком је изостављено име коауторке текста Евройска збирка йодайака о кримиалииеейу и кривичном йравосуђу: каракиееристиике и значај за развој евидениија криминалитетейа у Србији, Љиљане Стевковић. Извињавам се ауторки због ове грешке. Цео текст са исправљеним навођењем аутора се налази на сајту часописа www.socioloskipregled.org.rs Овом приликом објављујемо исправку као и резиме текста на српском и енглеском.

\section{Весна Николић-Ристановић}

Факултет за специјалну едукацију и рехабилитацију, Универзитет у Београду

\section{Љиљана Стевковић}

Институт sа криминолошка

и социолошка истраживања, Београд

\section{ЕВРОПСКА ЗБИРКА ПОДАТАКА О КРИМИАЛИТЕТУ И КРИВИЧНОМ ПРАВОСУЂУ: КАРАКТЕРИСТИКЕ И ЗНАЧАЈ ЗА РАЗВОЈ ЕВИДЕНЦИЈА КРИМИНАЛИТЕТА У СРБИЈИ}

Сӣайистиике криминалийейа, уйркос бројним крийикама и недостиацима, йредстиављају значајан извор йодайака о криминалийеӣу као масовној йојави. При йоме, йолиијске сииаиистиике као евиденције о иријављеном криминалитиейу, у смислу

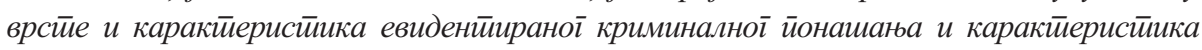

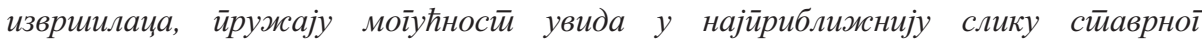
криминалитетета, како на националном, йако и на међународном нивоу. Рад има за цииь

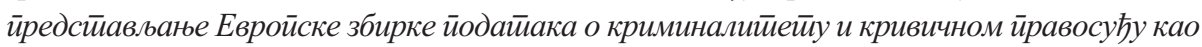

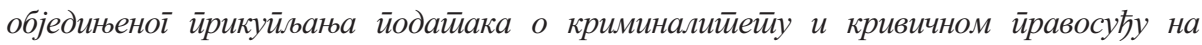

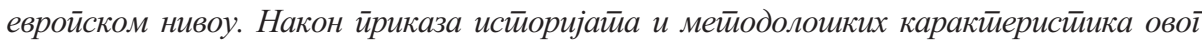
начина йрикуйљања и ириказивања йодайака, у раду ће бийи йредстиављени йодащи

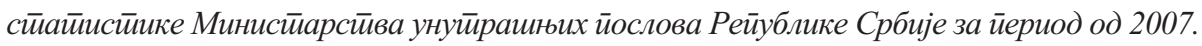

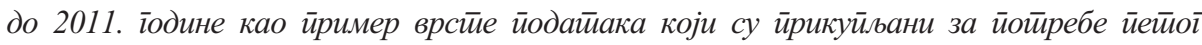
издаюа Евройске збирке йодайака о криминалииетичу и кривичном ирравосуђу. Узакључку 
је указано на значај који Евройска збирка йодайака има за унайређење евиденитирана и

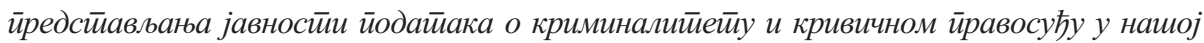
земльи, за йоређене са сийуацијом у друіим земьама, као и за йланирање сиирайейије сирречавана и сузбијана криминалитетета у Србији.

Кључне речи: Евройска збирка йодайака о криминалийеӣу и кривичном

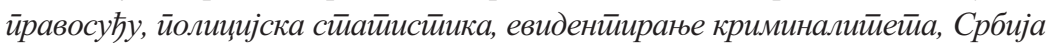

$$
* * *
$$

\section{Vesna Nikolić-Ristanović}

Faculty of Special Education and Rehabilitation,

University of Belgrade

\section{Ljiljana Stevković}

Institute of criminological and sociological research, University of Belgrade

\section{EUROPEAN SOURCEBOOK OF CRIME AND CRIMINAL JUSTICE: CHARACTERISTICS AND ITS IMPORTANCE FOR THE DEVELOPMENT OF EVIDENCE OF CRIME IN SERBIA}

Crime statistics, despite numerous criticisms and shortcomings, are an important source of data on crime as a mass phenomenon. In addition, police statistics as evidence of the reported crime, in terms of the type and characteristics of recordedcriminal behavior and characteristics of perpetrators, provide an insight into the nearest real picture of crime, both at national and international level. The aim of the paper is to present the European Sourcebook of Crime and Criminal Justice as a unified collection of data on crime and criminal justice at the European level. After presenting the background and methodological characteristics of this way of collecting and presenting the data, the statistical data of the Ministry of Internal Affairs of the Republic of Serbia for the period from 2007th till 201 $1^{\text {th }}$ as an example of the kind of data that were collected for the fifth edition of the European sourcebook of crime and criminal justice will be presented. In conclusion it was emphasized the importance of European sourcebook for improvement of the recording and public presentation of data on crime and criminal justice in our country, as well as for comparison with the situation in other countries and for planning strategies to prevent and supress crime in Serbia.

Keywords: European sourcebook of crime and criminal justice, police statistics, crime recording, Serbia 